\title{
COMBATING CRIMINAL LAW COMPLICITY IN THE CRIME
}

\section{Dombrovan N. V.}

\section{INTRODUCTION}

The proper criminal legal counteraction to the crimes committed by the accomplices depends to a large extent on the correct determination of the role of each of them in the commission of the crime, which is a necessary precondition for the punishment that would be appropriate to the nature and degree of participation of the accomplices in the crime. Unlike other accomplices (organizer, instigator, executor), the science of criminal law in Ukraine did not pay proper attention to the research of the legal evaluation of complicity.

The common law and practice approach is that this type of accomplice is considered the least socially dangerous among others. At the same time, the position of an accomplice in its content is to perform functions that generally make it possible to commit a crime by the executor and other accomplices. In doing so, this role of the accomplice is not limited solely to the physical or intellectual facilitation of the achievement of the common criminal purpose, but also to a certain extent contributes to strengthening the determination of other accomplices in the pursuit of the criminal intent.

Particularly important is the analysis of complicity a crime by a special subject, when the role of the accomplice is actually reduced to partial or complete fulfillment of the objective side of the crime, which, given the general principles of criminal law, does not receive a proper legal evaluation.

It should be noted that the objective complexity of socially dangerous acts committed in complicity, their multiple occurrences, the combination of different roles in the actions of one accomplice, necessitates the definition of clear criteria for differentiation of actions of different accomplices. In particular, this applies to the accomplice and the organizer (the latter may involve some form of assistance in committing the crime), the accomplice and the co-executor (the division of functions between co-executors may lead to one of them performing an auxiliary function), the co-worker and the instigator (the person inclining to committing the crime, and the person assisting it, influence the decision of the perpetrator to commit the crime).

Significant contribution to the study of criminal responsibility for complicity the crime was made by such scholars as: P. Andrushko, M. Bazhanov, A. Benitskyi, Yu. Bila, V. Glushkov, D. Gorbachev, N. Gutorova, A. Zakalyuk, O. Kvasha, O. Kostenko, O. Lytvak, M. Melnyk, 
A. Muzyka, V. Tatsiy, V. Tyhyi, M. Havroniuk, S. Hiliuk, S. Shapchenko, N. Yarmysh, S. Yatsenko and other scientists. Despite the considerable amount of research done by the institute on complicity in crime, many questions remain debatable and need further analysis, in particular to clarify the nature of complicity, distinguishing it from other accomplices, differentiating the criminal liability of an accomplice, and more.

Therefore, it is relevant and important to conduct a scientific study aimed at ensuring effective criminal and legal counteraction to complicity a crime.

\section{Genesis of complicity in the history of criminal legislation}

In the theory of criminal law was a common view, according to which the institution of complicity was completely identified with Art. 19 of the Criminal Code of Ukraine 1960 (the content of this provision is partially reproduced in Articles 26 and 27 of the current Criminal Code of Ukraine). So, speaking about the overall importance of the complicity institute, $\mathrm{N}$. Gutorova notes that the complicity institute extends its action to all cases of intentional joint committing of a crime, establishing objective and subjective indications of complicity, the limits of criminal liability of accomplices and peculiarities of assignment.

The institute of complicity in crime is one of the instruments of the state's implementation of criminal policy. Historically, its official function has been to justify the criminal responsibility of persons who did not commit the objective side of the crime themselves, but in various forms assisted it. Traditionally, in law, it was done through the identification of types of accomplices and the differentiation of their responsibilities.

Already in ancient sources of domestic criminal law we find mention of persons who assist in committing a crime - accomplices. However, despite the aforementioned obviousness of the content of the actions of the accomplice of the crime, both in theory and in law enforcement practice, there remain many issues related to their legal assessment.

Complicity was known for a long time, it did not require consolidation in the law, as it was obvious ${ }^{1}$. In the opinion of M. Kovaliova: "That is why no one and in the head came to specifically determine responsibility for the joint activity of several persons" ${ }^{2}$.

The first period of formation of complicity began in Rus. As P.Kolosovskyi rightly pointed out: "In Rus, much attention was paid to the

\footnotetext{
${ }^{1}$ Пипия А.Г. Ответственность за совместную преступную деятельность по римскому и западноевропейскому раннефеодальному праву. Правоведение. 1990. № 6. С. 91-96.

${ }^{2}$ Ковалев М. И. Соучастие в преступлении : в 2 т. - Свердловск : СЮИ, 1962. Т. 2. $274 \mathrm{c}$.
} 
mental activity of the perpetrator, not his actions" ${ }^{\text {. }}$. Thus, despite the fact that the Ruska Pravda did not contain the legal acts established by the criminalization of the accomplice of the crime, in general, they played an important role in establishing the institution of complicity. According to V. Momotov, this source is important not only in connection with the first mention in the history of domestic criminal law about complicity in the commission of a crime, but also sanctions. "For the sanction provided for in this article (Article 40 of the Short Edition of the Ruska Pravda) reflects the process of formation of criminal law itself as a public right, for which the sphere of social interest stands in the first place" 4 .

The second period in the formation of the Institute of complicity falls at the end of the fifteenth century and was related to the adoption of Sudebnyk 1497. This first codified legal act, like previous sources, did not contain the concept of complicity, its forms and types. However, Art. 19 provided for the release of boyars and scribes for complicity in wrongful accusation. It is also worth mentioning the Bilozerska diploma of 1539 , in which the concealers were clearly identified with the direct performers.

Sudebnyk 1550 already contained more rules governing complicity. The progressive vector of the development of this institute is evidenced by the securing of the special responsibility of guardians and indulgants towards all

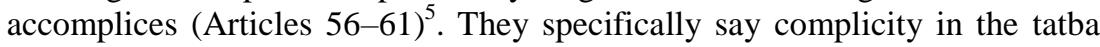
(abduction).

In the view of A.Pluzhnikova: The courts of 1497 and 1550 did not contain the established rules on complicity, as the basis of responsibility was the admission of guilt and people voice ${ }^{6}$. But as the spheres of criminal activity carried out in complicity, the increase in the number of such crimes, as well as the change in the number of participants in the crimes, there was a need to differentiate the responsibilities of the guards, the depositors and other accomplices. All this eventually led to the isolation of their species, which was consolidated in the Cathedral Code in 1649.

In the view of Ye.Epiphanova: "The conclusion, along with the interpretation of other legal institutions, gave a brilliant model of legislative

\footnotetext{
${ }^{3}$ Пипия А.Г. Ответственность за совместную преступную деятельность по римскому и западноевропейскому раннефеодальному праву. Правоведение. 1990. № 6. С. 91-96.

${ }^{4}$ Пипия А.Г. Ответственность за совместную преступную деятельность по римскому и западноевропейскому раннефеодальному праву. Правоведение. 1990. № 6. С. 91-96.

${ }^{5}$ Пипия А.Г. Ответственность за совместную преступную деятельность по римскому и западноевропейскому раннефеодальному праву. Правоведение. 1990. № 6. С. 91-96.

6 Плужников А.В. Соучастие в преступлении (проблема соучастия общего и специального субъекта): автореф. дис. на соискание науч. степени канд. юрид. наук : 12.00.08. Москва, 2008. 22 с.
} 
understanding of complicity"7 . In Art. 12 of Chapter X was for the first time a legislative system of types of accomplices, which was based on the selection of the main culprits (instigators and executors) and minor - assistants and patrons (accomplices). The main culprits were those who directly committed the crime (physically, the main culprits) or took action earlier than others from the very beginning of the crime. Participation is psychological, spiritual, such as advice, command, incitement, was also recognized. Assistants to the main perpetrators of the crime were usually called comrades. These persons contributed to the commission of the crime by unlawful acts or omissions, or delivered funds in advance for the commission of the crime or eliminated obstacles to the commission of the crime.

The third period of development of the principle of individualization of responsibility of accomplices is connected with the publication of the "order" of Katerina the Great in 1767. For the first time in the history of domestic criminal law "Order" quite clearly distinguished between the executor and other accomplices ("accessory") and demanded the establishment of different punishment them. At the base of this difference was the assessment of the contribution of each accomplice to the crime and correlated his responsibility. These provisions have been further developed. Thus, in 1833, the Criminal Code was put into effect, which made significant changes to the institution of complicity in crime. Thus, Section I of the First Book of Volume XV contained the norms of "Crimes" 8 . They distinguished the following categories of participants: a) associates who, in the aggregate, brought the crime into action, and invaders who acted together with others, but before their first put intent and consent to the others, or the former gave an example of committing the crime to others; b) assistants and participants, of which there were only six categories. The normative act also implemented the principle of individualization of punishment.

Institute of complicity in the middle of the XVII century - the beginning of XVIII century continued its progressive development in the norms of domestic criminal law. For the first time, the legislator establishes the general principle of liability for complicity as a joint, unbundled participation in a single unlawful act. More detailed consolidation was found in the legislation of Peter I and the provision of complicity, which was first considered as a complex system of alternative actions covering both intellectual and physical assistance to the perpetrator.

\footnotetext{
${ }^{7}$ Пипия А.Г. Ответственность за совместную преступную деятельность по римскому и западноевропейскому раннефеодальному праву. Правоведение. 1990. № 6. С. 91-96.

${ }^{8}$ Пипия А.Г. Ответственность за совместную преступную деятельность по римскому и западноевропейскому раннефеодальному праву. Правоведение. 1990. № 6. С. 91-96.
} 
The fourth period. However, the most detailed development of the Institute of complicity was carried out only until the middle of the XIX century. The decision to punish criminal and correctional officials in 1845 was the result of the codification of criminal law in the Russian Empire. In Art. 13-17 the Codification distinguished between two types of complicity: complicity without prior agreement (osprey) and complicity with prior agreement (conspiracy). The definitions of the main culprits and participants were summarized in Art. 14. And the notions of guards, sub-contractors, instigators and accomplices were stated in Art. 15. Article 12 of the Code lists the components of an accomplice's actions: direct assistance to the main perpetrators of the crime; delivery of means for committing a crime, removing obstacles. According to Art. 13 assistants were persons who, although not directly involved in the commission of the crime, but of selfish or other personal kinds, assisted or undertook to assist with advice or instructions and communications, or to supply any other means of committing the crime, or by removing obstacles, or knowingly, before committing a crime, sheltering themselves, or promising to assist in the concealment of criminals or crime ${ }^{9}$.

Thus, the authors of the Code sought to provide the most comprehensive list of acts constituting complicity of a crime. This approach should be considered justified from the point of view of law enforcement, since the legal assessment of complicity often raises the need to distinguish it from involvement in a crime. The formal approach to punishment of accomplices based on the objectively fulfilled role of each actor also implies from the same positions. The criminal conviction of 1903 not only significantly simplified the system of types of complicity, attributing to them the executor, instigator and accomplice, but also gave definition of complicity: "Acts committed by several persons who agreed to commit it or acted knowingly jointly".

Therefore, the main feature of complicity under the Criminal Code was the commonality of guilt. Art. 51 of the Code provides a list of participants, which include: a) the directly committed criminal act or persons who participated in its execution; b) inciting another to complicity in a criminal act; c) accomplices who have provided funds or assisted in the commission of a criminal act by advice, an indication or a promise not to obstruct it or to conceal it.

The assistants were persons involved in the crime itself, in terms of assistance in its execution. For complicity, it was important that there was a link between the accomplices and the perpetrators of the crime, proving an

\footnotetext{
${ }^{9}$ Пипия А.Г. Ответственность за совместную преступную деятельность по римскому и западноевропейскому раннефеодальному праву. Правоведение. 1990. № 6. С. 91-96.
} 
agreement to commit the intended crime. The accomplice always had to know that his actions would facilitate the commission of the crime.

Thus, the Criminal Code of 1903 gives a more concise definition of an accomplice, since the actions of its components displays information and the physical concealment of criminals. In addition, the Code introduced a fundamentally new approach to the responsibility of the accomplices of the crime. Thus, in particular, the instigator and the accomplice were punished when stipulated in the article of Code. If the assistance of an accomplice was not significant, then the punishment could be mitigated.

As a result of the historical and legal analysis of the rules on complicity in crime contained in the main monuments of domestic law, a number of conclusions emerge: despite the fact that the legislative definition of complicity was formulated only until the middle of the XIX century by Code, certain provisions on the types of accomplices, including the associate, were enshrined in early sources of domestic law (in the Belozerska diploma of 1539 and Sudebnyk 1550); the definition of complicity occurred against the background of delineating complicity from involvement in a crime; traditionally, in the sources of law throughout its development, the concept of an accomplice is revealed through the listing of his actions; in different periods of formation of criminal law, the content of the objective side of the assistance differs, it was most widely defined in Art. 12 and 13 of the Criminal and Correctional Code of 1845.

To summarize, we emphasize that the narrow understanding of complicity in the current criminal situation related to the increase of complicity crimes offered by the legislator in the Criminal Code of Ukraine does not correspond to the current criminal situation. An important role here is played by the limitations of criminal prevention against persons who intentionally contribute to criminal activity.

\section{Grounds of criminal liability of the accomplice from the position of criminal consistency theory}

The criminal liability of the accomplice for aiding and abetting the crime should be based on certain theoretical principles that would serve as a fundamental basis for addressing the issue of the social danger of this type of accomplice. This issue deserves special attention, both in the context of defining the principles of differentiation of legal consequences that occur in committing a crime in complicity with roles, and in the context of individualizing the punishment for their acts.

Such a fundamental basis is the theory of complicity, the scientific development of which was carried out by a number of domestic and foreign scientists to find out the legal nature of complicity, the place and role of each 
accomplice in the crime, the signs of causation in the actions of different types of accomplices. So, only the presence of complex, logical and consistent teaching can ensure proper criminal and legal response not only to typical but also atypical manifestations of intentional joint participation in committing a crime, for example, if the perpetrator does not finish the crime voluntarily refusing to commit other accomplices crime, excesses of executors (co-executors), etc ${ }^{10}$.

It should also be borne in mind that only through the general theory of complicity can the role of the accomplice be ascertained, which in turn must be reflected in the rules of criminal law and, in view of such a role, must the relevant law be applied in practice.

However, it should be noted that issues related to the concepts of complicity theory are some of the most difficult in criminal law theory and have not been resolved for a long time. Thus, scientists argue for different theories of complicity accessory (non-independent) or independent nature of complicity. Such a condition also causes inconsistent resolution of the question of the legal consequences of the accomplices for their socially dangerous acts and other consequences of behavior that has a criminal legal value. As V. Tkachenko, in the science of criminal law, there is probably not as much scientific work than those devoted to the Institute of complicity. However, we can say with confidence that it is the focus of many problems that have not yet been fully resolved: regarding the content of the notion of complicity, criteria for classification of its forms, grounds for liability of accomplices, etc ${ }^{11}$.

The question of the legal nature of complicity is linked to the general theory of criminal liability, which is based on fundamental principles, which obviously must be adhered to when dealing with the criminal liability of accomplices. In this context, it is necessary to cite F. Burchak's thesis, who argued that it is impossible to speak of the accomplice's responsibility for the actions of the executor without contradicting the basic ideas of criminal law and justice ${ }^{12}$. First of all, this thesis deals with the principle of personal responsibility, according to which a person is only responsible for the actions he or she has committed. F. Burchak's position is certainly grounded in the context of such types of accomplices as the organizer, instigator and accomplice who, according to their role in the criminal liability law, do not perform the objective side of the crime provided for in the Special Part of the Criminal Code of Ukraine.

${ }^{10}$ Кримінальне право України. Особлива частина : підручник/ за ред. В. В. Сташиса, В. Я. Тація. Вид. 4-е, переробл. і допов. Харків : Право, 2010. 608 с.

${ }^{11}$ Арутюнов А. Пособник преступления. Закон и право. 2002. № 11. С. 28-31.

12 Бурчак Ф.Г. Соучастие: социальные, криминологические и правовые проблемы. Киев : Вища школа, 1986. 208 с. 
Researchers analyzed within this section state that accessory theory of complicity first found its place. In the Criminal Code of France in 1791, and later in the Criminal Code of 1810. This concept was developed by representatives of the classical criminal law school. Initially, she assumed responsibility for another's crime, as some of her supporters adhered to the position of indeterminism and absolute freedom of will. The content of the accessory theory of complicity is revealed in the thesis that the social danger of the accomplice's actions directly depends on the nature of the performer's actions, which determines the accessory nature of the complicity ${ }^{13}$.

On the basis of the accessory theory of complicity in the science of criminal law, there are two main provisions: 1) the accomplice should be held liable only for the presence of signs of crime in the actions of the executor (it implies that the liability of the accomplice can only take place if the executor is prosecuted); 2) the accomplice is held liable under the norm of the criminal law, according to which the executor is prosecuted.

In particular, in the context of the validity of the accessory theory of complicity, I. Heifetz noted that the principle of division of labor, which is so conducive to the development of the economy, is very dangerous for society when used by thieves. Meanwhile, by destroying complicity and incriminating everyone with their own actions, the theory leads to a decrease in punishment in these cases ${ }^{14}$.

In turn, the theory of the autonomous nature of complicity is that each accomplice performs his or her own composition of the crime, and therefore the act of each is connected with another but independent crime ${ }^{15}$. The proponent of the same theory is A. Zelinskyi, who claimed that each accomplice was responsible for the acts they committed that contained the crime. Their responsibility is not derivative, but independent. In this sense, complicity is not accessory ${ }^{16}$.

In the context of the issues under study in this section, it is important to note that scholars point out that the role of the executor in matters of criminal liability of other accomplices is not exaggerated. As F. Burchak noted, the accomplices of the accomplished crime will only take place in the actions of

13 Кузнецов В.В., Савченко А.В. Теорія кваліфікації злочинів : підручник. Київ : Алерта, 2013. $320 \mathrm{c}$.

${ }_{14}$ Кримінальне право України. Особлива частина : підручник / за ред. В. В. Сташиса, В. Я. Тація. Вид. 4-е, переробл. і допов. Харків : Право, 2010. 608 с.

15 Плужников А.В. Соучастие в преступлении (проблема соучастия общего и специального субъекта): автореф. дис. на соискание науч. степени канд. юрид. наук : 12.00.08. Москва, 2008. 22 с.

${ }^{16}$ Кримінальне право. Загальна частина : підручник / за ред. А.С. Беніцького. Київ : Істина, 2011. $1112 \mathrm{c.}$ 
the accomplices if the perpetrator of the objective side of a particular crime is executed by the executor. In this and only in this sense, as noted by the scientist, the organizer, instigator and accomplice inherit the fate of the executor: the presence of a completed crime in the actions of the executor determines the composition of the completed crime in their actions, which, in turn, leads to criminal responsibility of the executor for the completed crime and his accomplices for organizational activity, inciting or aiding and abetting a crime ${ }^{17}$.

In addition to the assessment of the accessory and the theory of selfresponsibility of the accomplices, other theoretical concepts justified in explaining the legal nature of the complicity are justified in the science of criminal law. An example of such a concept is justified by D. Bezborodov is the idea of a joint criminal act, the essence of which is the commonality of encroachment on the interests protected by law. At the same time, the communion of action is conditioned by a certain combination of objective and subjective properties of the organization of actions (inaction) of several persons involved in committing a crime. Responsibility for committing a crime must be based on the following principles: first, the principle of inevitability of responsibility for each participant; secondly, on the principle of equal grounds of criminal responsibility for joint committing of a crime and for committing a crime by one person; thirdly, on the principle of independent responsibility of each participant of the action ${ }^{18}$.

At the same time, the scientific literature emphasizes that the theories analyzed cannot autonomously provide a systematic explanation of the legal nature of complicity or of various types of accomplices, and therefore cases where aspects from another are added to one or another theoretical basis. The same applies to the legal regulation of accomplices "liability in the Criminal Code of Ukraine, which contains rules that can be considered both based on the accessory theory of complicity and the theory of the independent nature of the accomplices" liability.

Thus, in particular, the research which was conducted by O. Kvasha allowed us to conclude that the rules governing certain aspects of the accomplices' responsibilities do not clearly reflect one theory of complicity. As an example of reflection of the theory of accessory, the scientist cites the provision according to which the accomplices (organizers, instigators, accomplices) are responsible for the crime committed by the executor

17 Бурчак Ф.Г. Соучастие: социальные, криминологические и правовые проблемы. Киев : Вища школа, 1986. 208 с.

18 Дядькин Д.С. Соучастие в преступлении: монография. Москва: Компания Спутник. 2004. 156 c. 
(co-executors), and their actions are qualified under the article of the Special Part of the Criminal Code, which is qualified by the actions, but with a mandatory reference to the relevant part of Art. 27. Also according to Part 4 of Art. 29 of the Criminal Code, in case of committing the perpetrator of the crime, the other accomplices are criminally responsible for complicity in the crime. In turn, provisions based on the opposite theory are the rules of legal evaluation of the voluntary refusal of the organizer, accomplice, instigator, as well as rules governing the legal consequences of the excess of the executor and according to which the accomplices are not criminally responsible for the act committed by the executor not covered by their intent (Part 5 of Article 29 of the Criminal Code) ${ }^{19}$.

Given the above, a rather widespread and well-grounded at the present stage seems to be a mixed position, which involves a combination of the two approaches analyzed, in other words, their symbiosis. In particular, this position is based on the claim that both points of view are opposed to each other in the literature, but these views have the right to coexist. They need not be contrasted ${ }^{20}$. The "mixed" theory of responsibility of the accomplices is substantiated by S.Avetisian, who states that the corresponding theory is caused by the fault of each of the accomplices, mixed actions in the process of planning the crime, as well as a mixed causal link between their actions and the damage that has occurred ${ }^{21}$.

Thus, we can conclude that the relevant provisions should also apply in determining the role and legal nature of complicity in a crime, the grounds of criminal liability of this type of accomplice. In particular, taking into account the value of the accessory theory of complicity gives an explanation of the grounds of criminal responsibility of a person who did not participate in the performance of the objective side of a certain act, but only facilitated its commission. In turn, the theories of self-responsibility of the accomplices make it impossible to find cases of "excessive" criminalization, which, in our opinion, would have occurred in the case of complicity in the crime, if it had not been completed, or in the case of criminalization an accomplice of actions not covered by his intent.

The significance of complicity theory is to explain what constitutes the criminal liability of the accomplice, in particular, given the fact that the actions of other accomplices do not contain the objective side of the composition of a

${ }^{19}$ Гуторова Н. А. Соучастие в преступлении по уголовному праву Украины: учеб. пособ. Харьков: ООО “Рубикон П”, 1997. 101 с.

20 Науково-практичний коментар Кримінального кодексу України/ за ред. О. М. Джужі, А. В. Савченка, В. В. Чернєя. Київ: Юрінком Інтер, 2018. 1104 с.

21 Аветисян С. С. Ответственность за подстрекательство и пособничество в преступлении со специальным составом. Закон и право. 2004. № 2. С. 37-39. 
particular crime and, therefore, there is no reason to claim the existence of a "classic" causal link between the actions of other accomplices and the consequences that have come from the direct actions of the perpetrator of the crime. V.Nawrockyi emphasizes that aiding, like any complicity in a crime, is an activity that is causally related to the activity of the perpetrator ${ }^{22}$.

The raised problem is that the criminal law of Ukraine is based on the philosophical postulate that a person can be held criminally responsible only for those negative changes in the objective world that were caused by the behavior of that person, that is, if there is a causal link between acts and socially dangerous consequences that have occurred ${ }^{23}$. That is why, in view of such a postulate, it can be argued that the grounds of criminal responsibility of an accomplice who provided the other person with the information necessary for committing a crime to the time of the stay of a person in a certain room, differ from the grounds of criminal responsibility of the executor, whose actions directly led to negative changes the objective world. Therefore, this postulate requires some clarification in the aspect of responsibility of the person, who facilitates the commission of a crime, whose actions do not directly lead to negative changes. Thus, the objective circumstances of specific socially dangerous acts involving other accomplices (organizer, instigator or accomplice) require special interpretation from the standpoint of the objective manifestation of their actions and the criminal result.

In view of the above, it should be noted that with respect to causation in the science of criminal law there is a position that, for all accomplices, a socially dangerous consequence resulting from the direct actions of the performer is causally related only to the act of the performer, whereas the actions of other accomplices are not by reasons, but only by the conditions of occurrence of the corresponding consequence ${ }^{24}$. The national scientist O. Kostenko distinguishes two cause-and-effect relationships when committing a socially dangerous act in complicity: 1) between the act of the organizer, the instigator, the accomplice and the onset of the state of readiness to commit a specific crime by the performer $(\mathrm{s}) ; 2)$ between the act of the executor (s) and the onset of criminal consequences provided for by the criminal law norm of the Special Part of the Criminal Code ${ }^{25}$.

${ }^{22}$ Навроцький В. О. Основи кримінально-правової кваліфікації: навч. посіб. Київ : Юрінком Інтер, 2006. 704 с.

${ }^{23}$ Вознюк А. А. Організовані форми співучасті за Кримінальним кодексом України. Науковий вісник національної академії внутрішніх справ. 2015. № 2. С. 97-106.

${ }^{24}$ Вечерова $€$. Співучасть як один із базових інститутів сучасного кримінального права. Право України. 2016. № 10. С. 170-176.

${ }^{25}$ Кузнєцов В.О., Гіжевський В.К. Кримінальне право України : навч. посіб. Київ : Кондор, 2008. 208 с. 
Scientist O. Kvasha states that causality in the structure of complex complicity has the following features: each accomplice's actions precede the onset; each accomplice contributes his or her own actions for the consequence (role distribution of causation); the activity of the performer depending on the previous or related activities of other accomplices; a criminal consequence is created by the joint, united actions of all participants in the crime. The actions of an individual accomplice, including the performer, cannot be considered in isolation from the complicity system, since in such a case they lose the properties of interconnection, interaction, and therefore the community, which is the essence of complicity as a system as a whole. At the same time, it is not necessary to over-generalize the participation of each of the accomplices and deprive them of their own (role) "contribution" to the criminal result. The actions of an accomplice cannot be "dissolved" in the concept of "common cause" when the role character of the actions of each of them cannot be distinguished. This does not meet the principles of criminal law of Ukraine ${ }^{26}$.

In the context of the above approach, we consider it prudent to draw attention to the thesis that the actions of an individual accomplice, including the performer, cannot be considered in isolation from the complicity system, since they in this case lose the properties of interconnection. The sign of integrativeness, for example, allows to find a legal explanation of the grounds of criminal liability of the accomplice in case if the perpetrator of the crime committed by him has used it.

Structure is defined as the internal base of the system, which is caused by the existence of stable connections between its parts (elements, subsystems) ${ }^{27}$, and the system is a complete integration of elements, which is based on a certain structure with a clear hierarchy of causation and interaction ${ }^{28}$. Traditionally, an accomplice is considered a lower link in such a structure, which is conditioned by the construction of Article 27 of the Criminal Code of Ukraine, and, as will be shown later, is enshrined in foreign criminal law. While the national scientist V. Nawrockyi is skeptical of this position. The scientist notes: "It indicates that when committing a crime, in complicity with the distribution of roles, may combine the performance of several such roles, in particular, the instigator and organizer, instigator and accomplice".

In general, it should be noted that this approach to understanding the essence of causation in crimes committed in complicity, also gives grounds to

${ }^{26}$ Кваша О. Актуальні проблеми розвитку інституту співучасті у злочині. Право України. 2014. № 5. С. 167-177.

27 Кримінальне право України. Загальна частина: підручник / за ред. В. Я. Тація, В. І. Борисова, В. І. Тютюгіна. Вид. 5-е, переробл. і допов. Харків : Право, 2015. 528 с

28 Вознюк А. А. Трансформація співучасті: поняття та форми. Боротьба 3 організованою злочинністю і корупиією (теорія і практика). 2014. № 1 (32). С. 68-71. 
conclude that neither the accessory theory nor the theory of the independent nature of the liability of the accomplices is not capable of purely provide the grounds of criminal liability accomplices.

From the perception of one or another theory of complicity depends largely on the approach to solve the question of the termination of the criminal act by each of the accomplices. In particular, the researcher of the questions of the law in time M. Bloom's conclusion is that according to the organizer, the time of committing the crime is the time of committing by other accomplices all the actions that led to the desired result, since he organized and managed the crime. For the instigator, the time of committing the crime is the moment when he inclined the perpetrator to commit the crime. For the accomplice, the time of the crime must be determined on the same principle. It follows that the organizer of the crime must be responsible under the law under which the perpetrator of the crime is responsible, and the instigator and accomplice under the law that acted during the commission of the acts that facilitated the commission of the crime ${ }^{29}$. We should agree with the above approach to the question of the law that should be applied to carry out a legal assessment of the accomplice's actions, since in our view the opposite approach would be contrary to the general principles of criminal law. At the same time, it should be noted that in such circumstances the rule under which the accomplice is liable under the relevant part of Article 27 and that Article (part of the Article) of the Special Part of the Criminal Code, which provides for a crime committed by the perpetrator, will not be fully implemented ${ }^{30}$.

Along with the discussion about the time of committing a crime, each of the accomplices also faces, the problem of finding out where they are committing the crime, especially in cases where the place of committing a crime influences the criminal law evaluation of a person's actions. In this context, M.Bloom states that: 1) the place of the perpetrator's act is decisive and must be recognized as the crime scene for the other accomplices (instigator, accomplice); 2) the place of actual commission by each of the accomplices stipulated by the agreement of actions (inaction) is the place of commission of the crime, regardless of the place where the crime was committed by the perpetrator; 3) the place of committing the crime of complicity is for all accomplices the place where the perpetrator committed the criminal acts, and for each accomplice there is also the place where they

${ }^{29}$ Кваша О. О. Співучасть у злочині: структура та відповідальність. Луганськ : РВВ ЛДУВС імені Е. О. Дідоренка, 2013. 560 с.

30 Науково-практичний коментар Кримінального кодексу України / за ред. М. І. Мельника, М. І. Хавронюка. Вид. 9-те, переробл. і допов. Київ : Юридична думка, 2012. $1316 \mathrm{c}$. 
were directly perpetrated by acts causally related to the actions of the perpetrator and contributing to the overall criminal intent ${ }^{31}$.

Thus, both the issue of the time of the crime and the place of its perpetration are related to the article of the Special Part of the Criminal Code, which establishes responsibility for a specific socially dangerous act. At the same time, the analysis of scientific works shows that the supporters of the accessory theory of complicity substantiate the position according to which the crime is described exclusively in the Special part of the Criminal Code, and therefore its commission cannot be charged to persons (organizer, instigator, accomplice) whose actions are absent.

However, the opposite position is justified in the science of criminal law. The composition of a crime is a system of attributes that is necessary and sufficient to recognize that a person has committed a crime and to prosecute it. The composition of the crime is an act determined by the criminal law, and not only the Special but also the General Part of it ${ }^{32}$.

We agree that it is inadmissible, at the present stage of the development of criminal law, to apply a simplified approach to the assessment of complicity only as the act of an executor, in addition to the actions of other accomplices. In order to ensure proper criminal-law protection of the order of public relations, such an approach to crimes committed not only by the perpetrators but also by other accomplices, should provide for a supplement to the Special Part of the Criminal Code of Ukraine, which would establish this type of responsibility also for the organizers, accomplices, instigators. An appropriate way of dealing with criminal liability has been implemented, for example, in the Kingdom of Norway, the General Part of the Criminal Code which does not contain the principles of complicity of the accomplices, instead, certain types of socially dangerous complicity are enshrined in the articles of the Special Part of this Code along with the main act perpetrated by the perpetrator. Obviously, in this context, one or the other approach to the construction of the law on criminal liability should be evaluated from the standpoint of the study of historical traditions and scientific views established in a particular country. Unlike the Norwegian, which is characterized by considerable casuisticity, the domestic Criminal Code contains mostly abstract formulations, which are not characterized by excessive detail and attachment to specific life situations.

${ }^{31}$ Кримінальне право України. Загальна частина : підручник / за ред. В. О. Меркулової, В. Я. Конопельського. Одеса : ОДУВС, 2017. 432 с.

32 Кваліфікація злочинів: навч. посіб. / за ред. О. О. Дудорова, Є. О. Письменського. Київ: Істина, 2010. 430 с. 
Thus, consideration of the basis of the criminal liability of the accomplice should be based not only on the assessment of the norms of the Special Part, but also on their inseparable connection with the norms of the General Part of the Criminal Code, which determines which of the ways of promoting the perpetration of socially dangerous acts are recognized as complicity is the basis for criminal offenses.

Among other things, the fact draws attention that scientists pay considerable attention to assessing the intent of the accomplices when determining the essence of complicity. Thus, in the context of the accessory theory of complicity, it is stated that the dependence of accomplices' liability on the responsibility of the performer can only be said in the sense that the performer realizes the criminal intentions of the accomplices, and if he fails to realize the criminal intent of the accomplices, to achieve the criminal result, then the responsibility of other accomplices as well as for the perpetrator, there is a preparation or attempted crime ${ }^{33}$.

In turn, in the aspect of the theory of the independent nature of the responsibility of the accomplices, the scientists state that although the criminal intent of all accomplices is embodied by the executor, they must all bear their own responsibility, since the activity of each accomplice has an independent value $^{34}$. The doctrine of complicity is based on the provisions of community of the intent of the accomplices, however, it is false that only the executor realizes the criminal intentions of the accomplices, since in many cases the accomplishment of the objective party by this accomplice would be impossible without fully accomplished roles by other accomplices: developing a plan, inclining to commit a crime, or making and providing tools for committing a crime, etc. Also, in this context, we consider it appropriate to pay attention to the provisions of the English criminal law doctrine that have established the "common criminal purpose" rule: one person is responsible for the other's actions to achieve the common criminal purpose for which they were united. This rule does not apply to actions that go beyond the scope of a joint venture. In other words, if the perpetrator deviates to a large extent from the assault in question and deliberately performs the other, then only he is criminally responsible for the crime. Another accomplice is responsible for the crime he actually committed ${ }^{35}$. Thus, the existence of legislative and

${ }^{33}$ Ткаченко В. І. Форма співучасті як кримінально-правове поняття. Вісник Київського національного університету ім. Тараса Шевченка. 2007. № 74-76. С. 144-146.

${ }^{34}$ Мельник М. І. Види співучасників за новим Кримінальним кодексом України. Право України. 2001. № 11. С. 69-74.

35 Уголовный кодекс Республики Беларусь : Закон Республики Беларусь от 09 июля 1999 г. № 275-3. URL: http://pravo.by/document/?guid=3871\&p0=hk9900275 (дата звернення 11.12.2019 p.) 
theoretical provisions regarding the consequences of the excess of the perpetrator make it possible to state the specific nature of the common intent to commit the crime, as well as to participate in its implementation or deviation from it in the commission of the crime.

However, it should be borne in mind that the role of the accomplice is reduced not only to the joint committing of the crime, which occurs in the form of assistance, but also in the promise to contribute to the concealment of the crime. In turn, the promise of contributing to the concealment of a crime may not have a strong causal link with the consequences of the act of complicity, and therefore, obviously, such activity has certain peculiarities. In this form of assistance, at least two options should be distinguished. The first is the case where the existence of such a promise causes or confirms the determination to commit the crime by other accomplices, that is, makes it possible to commit the crime. The second, in turn, envisages an exclusively auxiliary function whereby a socially dangerous act will be committed regardless of whether or not a particular person promises to contribute to the concealment of a crime. In our view, the analysis and resolution of this issue largely depends on determining the aspects of the role-sharing of the accomplices' responsibilities in each case, which should ultimately be reflected in the specific type and amount of punishment for the crime of complicity.

A detailed theoretical analysis of the grounds of criminal responsibility of the accomplices makes it possible to investigate the rules of the law of Ukraine on criminal liability, which regulate certain aspects of the legal assessment of the actions of the accomplice from the standpoint of the basis on which concepts the relevant rules are based. In particular, this applies to articles that determine the criminal liability of accomplices (Article 29 of the Criminal Code), criminal liability of organizers and participants of an organized group or criminal organization (Article 30 of the Criminal Code), as well as the voluntary refusal of accomplices to commit a crime (Article 30 of the Criminal Code) $)^{36}$.

Thus, the manifestations of the accessory theory of complicity in the part of the liability of the accomplice are as follows: the accomplice is liable for the relevant part of Article 27 and that Article (part of the Article) of the Special part of this Code, which provides for the crime committed by the perpetrator (Part 2 of Article 29 of the Criminal Code); in the case of committing the perpetrator of the crime, the accomplice is criminally responsible for complicity in the crime (part 4 of Article 29 of the Criminal

\footnotetext{
${ }^{36}$ Мельник М. І. Види співучасників за новим Кримінальним кодексом України. Право Украӥни. 2001. № 11. С. 69-74.
} 
Code); the accomplice, in the case of committing a crime within an organized group or criminal organization, shall be criminally responsible for the crimes in which he participated in the preparation or commission (part 2 of Article 30 of the Criminal Code).

In turn, the manifestations of the independent nature of the responsibilities of the accomplices in terms of liability of the accomplice are the following: the attributes that characterize the identity of an accomplice are to blame only to him, other circumstances, which make the liability, and provided in the article of the Special Part of this Code, as indications of an offense affecting the qualifications of the perpetrator's actions, are to blame for the accomplice if he was aware of these circumstances (Part 3 of Article 29 of the Criminal Code); the accomplice is not criminally liable for the act committed by the executor, if it was not covered by his (accomplice) intent (part 5 of Article 29 of the Criminal Code); in case of voluntary refusal to commit a crime, the executor (co-executor) shall not be held criminally liable for the conditions provided for in Article 17 of this Code. In this case, the accomplice is criminally responsible for preparing for the crime or attempting to commit the crime, which the perpetrator voluntarily refused to commit (part 1 of Article 31 of the Criminal Code); not be held criminally liable for voluntary refusal of an accomplice if he has prevented the commission of a crime or has informed in due time the relevant authorities of the state of a crime which is being prepared or committed. The voluntary refusal of the accomplice is also the failure to provide him with the means or the means of committing the crime or the elimination of obstacles to the commission of the crime (Part 2 of Article 31 of the Criminal Code) $)^{37}$.

Thus, according to the results of the conducted research, it can be concluded that the legal consequences of complicity in a crime stipulated in the law on criminal liability are based on a combination of two theories of complicity: the accessory and independent nature of the accomplices' liability. At the same time, the mixed approach maximally contributes to the proportionality of the means of criminal responsibility and socially dangerous participation of a person in the negative change of the order of relations between people established in the state.

\section{CONCLUSIONS}

As a result of the historical and legal analysis of the rules on accomplice in a crime contained in the main monuments of national law, it was established: 1) the legislative definition of complicity was formulated only until the middle

37 Фріс П. Л. Кримінальне право України. Загальна частина: підручник. Вид. 3-тє, переробл. і допов. Одеса : Фенікс, 2018. 394 с. 
of the XIX century by the Criminal and Correctional Penalty of 1845 ; 2) in different periods of formation of criminal law the content of the objective side of assistance is defined in Art. 12 and 13 of the Criminal and Correctional Penalty of $1845 ; 3$ ) the definition of complicity occurred against the background of delineating complicity from involvement in a crime; 4) the concept of complicity is revealed through the listing of his actions; 5) there is an unjustified refusal of the legislator to indicate the physical concealment, the previously not promised concealment, as well as criminal indulgence in the actions of the accomplice.

The legal consequences of complicity a crime envisaged in the Criminal Code of Ukraine are based on the combination of two theories of complicity: accessory and the theory of the accomplices' self-responsibility. In view of the above, we point out the expediency of changing the domestic approach to the legislative definition of the term "accomplice" in part 5 of Article 27 of the Criminal Code of Ukraine.

\section{SUMMARY}

The article investigates the theoretical principles of the criminal liability of the accomplice and their implementation in the norms of the Criminal Code of Ukraine. According to the results of the study, it is concluded that the legal consequences of complicity a crime under the criminal responsibility law are based on a combination of two theories of complicity: accessory and independent. It is stated that the approach to formulating the definition of "accomplice", by using an exhaustive list of appropriate actions, does not contribute to ensuring the proper criminal legal response to all the variety of actions of this accomplice in committing a crime. It is substantiated that in formulating the legislative definition of an accomplice, as a kind of accomplice, to indicate the specific ways by which socially dangerous assistance to the commission of a crime is carried out. The norms of the Criminal Code of Ukraine, which define the principles of liability of the accomplice from the standpoint of accessory theory and from the standpoint of independent complicity theory, are distinguished.

It is established that on the basis of the accessory theory of complicity in the science of criminal law are considered two basic provisions: 1) the accomplice should be held liable only for the presence of signs of crime in the actions of the perpetrator; 2) the accomplice is held liable under the norm of the criminal law under which the executor is prosecuted. It has been found out that the theory of the self-character of complicity is that each accomplice performs his or her own crime, and therefore each act is related to another, but independent crime. The theoretical concept of "The idea of joint criminal act" is analyzed, which stipulates the joint encroachment on the interests protected 
by law. The "Mixed" theory of the complicity of the accomplices, which is caused by the fault of each of the accomplices, mixed actions in the process of planning the crime, as well as a mixed causal link between their actions and the damage that has occurred is disclosed.

It is proved that the rules governing certain aspects of the accomplices' responsibilities do not clearly reflect one theory of complicity.

\section{REFERENCES}

1. Аветисян C.C. Ответственность за подстрекательство и пособничество в преступлении со специальным составом. Закон и право. 2004. № 2. C. 37-39.

2. Арутюнов А. Пособник преступления. Закон и право. 2002. № 11. C. $28-31$.

3. Бурчак Ф.Г. Соучастие: социальные, криминологические и правовые проблемы. Киев : Вища школа, 1986. 208 с.

4. Вечерова $\mathcal{C}$. Співучасть як один із базових інститутів сучасного кримінального права. Право Украӥни. 2016. № 10. С. 170-176.

5. Вознюк А.А. Організовані форми співучасті за Кримінальним кодексом України. Науковий вісник національної академії внутрішніх справ. 2015. № 2. С. 97-106.

6. Вознюк А.А. Трансформація співучасті: поняття та форми. Боротьба з організованою злочинністю і корупиією (теорія і практика). 2014. № 1 (32). C. 68-71.

7. Гуторова Н.А. Соучастие в преступлении по уголовному праву Украины: учеб. пособ. Харьков: ООО “Рубикон П”, 1997. 101 с.

8. Дядькин Д.С. Соучастие в преступлении: монография. Москва: Компания Спутник. 2004. 156 с.

9. Кваліфікація злочинів: навч. посіб. / за ред. О.О. Дудорова, Є.О. Письменського. Київ: Істина, 2010. 430 с.

10. Кваша О. Актуальні проблеми розвитку інституту співучасті у злочині. Право Украӥни. 2014. № 5. С. 167-177.

11. Кваша О.О. Співучасть у злочині: структура та відповідальність. Луганськ : РВВ ЛДУВС імені Е.О. Дідоренка, 2013. 560 с.

12. Ковалев М.И. Соучастие в преступлении : в 2 т. - Свердловск : СЮИ, 1962. Т. 2. 274 с.

13. Кримінальне право України. Загальна частина: підручник / за ред. В. Я. Тація, В.І. Борисова, В.І. Тютюгіна. Вид. 5-е, переробл. і допов. Харків : Право, 2015. 528 с.

14. Кримінальне право України. Загальна частина : підручник / за ред. В.О. Меркулової, В.Я. Конопельського. Одеса : ОДУВС, 2017. 432 с. 
15. Кримінальне право України. Особлива частина : підручник / за ред. В. В. Сташиса, В. Я. Тація. Вид. 4-е, переробл. і допов. Харків : Право, 2010. 608 с.

16. Кримінальне право. Загальна частина : підручник / за ред. А.С. Беніцького. Київ : Істина, 2011.1112 с.

17. Кузнецов В.В., Савченко А.В. Теорія кваліфікації злочинів : підручник. Київ : Алерта, 2013. 320 с.

18. Кузнєцов В.О., Гіжевський В.К. Кримінальне право України : навч. посіб. Київ : Кондор, 2008. 208 с.

19. Мельник М.I. Види співучасників за новим Кримінальним кодексом України. Право України. 2001. № 11. С. 69-74.

20. Навроцький В.О. Основи кримінально-правової кваліфікації: навч. посіб. Київ : Юрінком Інтер, 2006. 704 с.

21. Науково-практичний коментар Кримінального кодексу України / за ред. М.І. Мельника, М. І.Хавронюка. Вид. 9-те, переробл. і допов. Київ : Юридична думка, 2012. 1316 с.

22. Науково-практичний коментар Кримінального кодексу України / за ред. О.М. Джужі, А.В. Савченка, В.В. Чернєя. Київ: Юрінком Інтер, 2018. $1104 \mathrm{c}$.

23. Пипия А.Г. Ответственность за совместную преступную деятельность по римскому и западноевропейскому раннефеодальному праву. Правоведение. 1990. № 6. С. 91-96.

24. Плужников А.В. Соучастие в преступлении (проблема соучастия общего и специального субъекта): автореф. дис. на соискание науч. степени канд. юрид. наук : 12.00.08. Москва, 2008. 22 с.

25. Ткаченко В. І. Форма співучасті як кримінально-правове поняття. Вісник Київського національного університету ім. Тараса Шевченка. 2007. № 74-76. С. 144-146.

26. Уголовный кодекс Республики Беларусь : Закон Республики Беларусь от 09 июля 1999 г. № 275-3. URL: http://pravo.by/ document/?guid=3871\&p0=hk9900275 (дата звернення 11.12 .2019 p.)

27. Фріс П.Л. Кримінальне право України. Загальна частина: підручник. Вид. 3-тє, переробл. і допов. Одеса : Фенікс, 2018. 394 с.

\section{Information about the author: Dombrovan N. V.,}

$\mathrm{PhD}$ in Law, Head of Scientific Work Organization Department, Odesa State University of Internal Affairs 1, Uspenska str., Odessa, 65000, Ukraine 